Original Research Paper

\title{
Researcher, Center for Contemporary Arab Studies, Georgetown University
}

\author{
Sabithulla Khan \\ ACCESS, Research Director, Arlington, VA, USA
}

Article history

Received: 09-06-2015

Revised: 03-12-2015

Accepted: 08-02-2017

Email: khanpgg@vt.edu

\begin{abstract}
This paper aims to provide an overview of the American Muslim giving patterns and specifically also attempts to map American Muslim giving, over the last 10 years, i.e., 2002-2012. It is also an attempt to capture the major shifts, trends and challenges to the Islamic philanthropic sector in the U.S. There are several competing theories about how the giving patterns and norms have shifted in the last years, from religious to secular giving and from international to local giving; as a result of regulations in the non-profit sector and also technological changes and innovation in fund-raising practices. Some scholars and advocacy groups have argued that there has been a substantial drop in American Muslim giving although there is no quantitative giving data to support this assertion. While there are a few qualitative studies and casestudies about American Muslim giving, there is neither a quantitative study that is nationally representative, nor a study that explains how and why this shift has occurred. This paper aims to remedy this gap and provides the context and narrative of American Muslim giving, using qualitative data, literature review and analysis of the three largest Muslim Humanitarian relief agencies and some quantitative data from the Center on Philanthropy Panel Study (COPPS) dataset at the Lilly School of Philanthropy, IUPUI, which is a nationally representative sample of U.S households.
\end{abstract}

Keywords: Giving, Religion, Secular Giving, American Muslims, U.S.A

\section{Introduction}

How is American Muslim philanthropy evolving? This simple question has not been answered sufficiently, with quantitative data. While several scholars have provided historical accounts (GhaneaBassiri, 2011; Siddiqui, 2014), there hasn't been a thorough quantitative or mixedmethods approach to addressing this question.

Further, while there are studies of ethnic groups in the U.S. and their community building initiatives, there haven't been comprehensive accounts of how philanthropy, identity and community building has occurred as an aggregate, though recent efforts by Kambiz Ghaneabassiri and Shariq Siddiqui have tried to address this lacuna. While one can argue that there isn't a considerable difference between how charitable giving is practiced among South Asian and Middle Eastern or
American Muslims, there are nuances in understanding and practices that make American Muslim giving unique, but not exceptional. I argue in this study that American Muslim philanthropy is undergoing a rapid evolution with new ideas, practices and norms shaping the field in a dramatic way. Young people and women are in particular shaping the field through their creative use of resources and talents and this article points out that this is a trend that needs to be studied.

Further, looking at the period between 2002-12, i.e., the last ten years offers us a good opportunity to analyze how understanding of religious and secular philanthropy have undergone a shift. The modern and the traditional are meeting and transforming each other, both within the Islamic tradition and outside of it. Carl Jung's observation about human personalities that: "The meeting of two personalities is like the 
contact of two chemical substances: If there is any reaction, both are transformed," may be true of the fields of Islamic Philanthropy and mainstream American notions of giving as well. While this paper does not argue for these two categories to be treated as two distinct entities, as there has always been a constant give and take between them. from the time of arrival of the first Muslims to the U.S. There is a perceptible difference between how charitable giving is conceptualized in Islam and in the U.S, which has been (arguably) influenced by largely Christian notions of giving (Jackson, Introduction).

This paper is organized as follows: Firstly, the paper examine the demographic context of American Muslim community, a brief history of how it has come to be in its current state. Next, it offers offer a literature review of the field of philanthropy in the U.S, looking at notions of giving (philanthropy) generally and specifically, in terms of Islamic Philanthropy. This will be followed by a close look at data from Giving USA and COPPS data from IUPUI, to make sense of the numbers and what insights this offers, as part of our narrative and finally, the paper offers an examination of some of the innovations in the field, especially in humanitarian development, both locally and internationally and how norms of giving are undergoing a shift and innovation is emerging as a theme in this space.

\section{Limitations:}

- Considering that giving data can be categorized in many ways i.e., giving locally or internationally; I have focused on giving to U.S based-institutions. Though diaspora giving is mentioned in brief, they do not form the core of my analysis

- The variable for religious affiliation RprefH2009 has Muslims, Rastafarians and others included in the sample. While there is reason to believe that a majority of them are Muslims, this is a caveat that must be included, in analysis

- Additionally, the number of Muslim families in the dataset is about 117 , even though this is a sizeable number, the number is small to do statistical analysis that is generalizable to the entire population. Hence, I have carried out basic descriptive statistical analysis and have carried out simple T tests ( comparison of means)

- Considering only two years i.e., 2001 and 2009 were used to compare philanthropy across two crosssections. This was a methodological choice, as this decade reflected enormous changes both in the identity of American Muslims as well as philanthropy towards them (Siddiqui, 2014)

\section{American Muslims: Demographics and Giving Behavior}

There are roughly about 3.5 million Muslims in the U.S. While the definite number is not known (because U.S census does not collect data on religious affiliation), these estimates are cited by scholars such as Kambiz GhaneaBassiri and more widely used by Pew Research. Other scholars and civil-rights organizations such as Council on American Islamic Relations have claimed that there are close to eight or ten million American Muslims (CAIR, 2011). Given the growth of the community and also conversion into Islam, the community is becoming visible in the U.S. The history of American Muslim giving is a history of the growth of the community and its institution building over the last four-five decades. The growth in both secular and religious institutions run by Muslims is an indication of the proliferation of philanthropy and giving in the community. This is despite of and over and above the diaspora giving and remittances that occur, on a regular basis.

A quick environment scan points out the growing diversity of the American Muslim philanthropic tradition. Recent efforts in humanitarian aid provision in post-conflict societies in the Middle East and North Africa (MENA) and Sub-Saharan Africa have given rise to a slew of organizations such as Islamic Relief, Muslims without Borders, Helping Hands, Mercy USA etc. Much of this has been in the realm of humanitarian and emergency relief, but there is also a growing realization for long-term social service and other forms of help to the needy domestically and internationally, as organizations such as Zakat Foundation have created a discourse about giving large part of their donations collected to local causes and emergencies. There are also many "secular" organizations i.e., associations for young American professionals, ethnic groups for lawyers, doctors and hundreds of smaller groups across the country, that are not necessarily faith-based but organized for American Muslims or Arab Americans that point to how vibrant the sector is (Najam, 2006). The recession of 2008 also lead to a need to focus on social services, as the demand for providing services to the homeless, disaster victims grew, substantially.

A recent study by the Council on American Islamic Relations (CAIR) points to a substantial growth in the number of mosques in the U.S (more than 2000) as of 2011. As the report goes on to say: "The US Mosque Survey 2011 counted a total of 2,106 mosques; as compared to the year 2000 when 1,209 mosques were counted-representing 74\% increase from 2000" (Bagby, 2011, intro). Further, the report shows how diverse the American Muslim population is. The author points out that: "Mosques remain an extremely diverse institution. 
Only 3\% of mosques have only one ethnic group that attends that mosque. South Asians, Arabs and African Americans remain the dominant groups but significant numbers of newer immigrants have arrived, including Somalis, West Africans and Iraqis" (Bagby, intro).

In this study, I look at giving through institutions and also individual giving. But given that the data on individual giving is important, Giving USA and COPPS datasets are used to provide a more complete narrative. Despite the limitations on available data, I believe if one looks at the field comprehensively, it is possible to tell the story of American Muslim giving rather accurately.

\section{Philanthropic Tradition in the U.S: A Brief Literature Review $^{i}$}

Before delving into the intricacies of American Muslim giving, I believe it is important to contextualize the giving practices in America, since there has been an enormous amount of give and take that has occurred between the various traditions. I believe there is wisdom in not treating "American" and "Islamic" traditions as separate analytical categories, as scholars such as Ghaneabassiri have pointed out, but rather to look at the relational aspects of the various traditions that form the palimpsest of the U.S. (GhaneaBassiri, 2011).

So, where does one begin, if one were to make sense of American Philanthropy? The logical answer would lead us to the Native American traditions, since they are the original inhabitants of the North American continent. Speaking of the period between 1700-1800 C.E, Jackson points out that: "In this period, we hear more Native American stories, including a Winnebago trickster tale that warns against providing only for oneself. These stories were no doubt in circulation prior to this century, but they were widely told at this time. To include them here is a reminder of the important Native American presence in the eighteenth century." This was also a period where African American traditions of giving and philanthropy thrived, as seen in the writings of anti-slavery Quaker Anthony Benezet. (Jackson, 2008, preface).

The writings and teachings of great scholars and poets through the centuries such as C.S. Lewis, John Winthorp, Alexis De Tocqueville (though not all American) have influenced the popular understanding of charity and philanthropy and the aesthetic dimensions of it. As C.S Lewis points out that we are all receiving, in one way or another. Despite our flaws, weaknesses, we receive much from our friends, wives, colleagues. As he points out, poignantly: "All who have good parents, wives, husbands of children, may be sure that at some times- and perhaps at all times in respect of some one particular trait or habit- they are receiving charity, are loved not because they are lovable but because Love Himself is in those who love them." (Qtd in Kass, p. 51).
This period was followed by a growing secularization and scientific management of philanthropy, as Jackson points out. As Walt Whitman, the great American poet, wrote:

"Love the earth and sun and the animals, despite riches, give almost to everyone that asks, stand up for the stupid and crazy, devote your income and labor to others.....read these leaves in the open air every season of every year of your life, re-examine all you have been told at school or church or in any book, dismiss whatever insults your own soul; and your very flesh shall be a poem and have the richest fluency not only in its words but in the silent lines of its lips and face and between the lashes of your eyes and in every motion and joint of your body." (Whitman, Leaves of Grass, qtd in Jackson 172).

The twentieth century saw the rise of the foundations, corporate lead efforts at philanthropy, by pioneers such as Andrew Carnegie, Rockefeller and others. The modern non-profit organization is an outgrowth of the long changes, permutations and combinations that have taken place over the decades preceding. With increasing professionalization and interest in the sector, employing over 10.7 million people, that is about $10.1 \%$ of the total workforce in the U.S (Grant space website).

\section{Notions of Giving Among American Muslims ${ }^{i i}$}

One can argue that notions of giving among American Muslims have been shaped by the mainstream notions of giving in the U.S, including both indigenous religious practices as well as other religious influences. One can argue that there has been a mutual give and take, in terms of philanthropic practices. This has been pointed out by many scholars of Philanthropy as well as American History (Ghaneabassiri, 2011; Siddiqui, 2014). As Siddiqui points out: "Instead of acquiring their religious identity directly through their ancestry, today's African American or "indigenous" Muslim Americans came to Islam largely through various African American movements well established after Reconstruction" (Siddiqui, 2014, p.35).

As Kambiz Ghaneabassiri points out in his book $A$ History of Islam in America, Islamic practices in America should be understood in a relational aspect, rather than as a set of beliefs that were rigid and unchanging. As he points out: "Many enslaved African interpreted their American context and negotiated their relations with black non-Muslims and white Christians. Generally speaking, Islamic beliefs and practices provided means by which Muslims in colonial and antebellum America sought poly-religious common 
ground with others. Islam was re-evaluated and reconfigured to define new poly-religious communal relations that crossed racial and religious boundaries" (2010, p.93). This means that the practices of charity were understood in terms that made sense to the slaves, in an environment that was not theirs to create.

He further argues in a specific context of giving i.e., in Saraka or Sadaqa (voluntary alms) that this act brought Muslims and non-Muslims into communal relations in antebellum America. As he points out that Muslims give Sadaqa to attain divine favor in the here and now, in the form of an un-answered prayers, the expiration of sins and assurance of general well-being for one's family, self or community against calamity or evil. This practice, he further adds was used by African Americans in the American South. He mentions Katie Brown of Sapelo Island who recalled her grandmother, who made a cake called Saraka that she distributed to her neighbors on Fridays. These practices, he argues became a way by which these women were able to form new communal boundaries. "The fact that their grandchildren did not associate the practice with Islam and thought Sadaqa referred to the cake itself rather than the practice of almsgiving suggests that their use of this practice was not intended necessarily to create an Islamic community but rather to Islamically sanction the existing community in which they participated" (GhaneaBassiri, 2011, p.72).

To understand how the American Muslim giving patterns fit into the larger narrative, it is critical to understand the broader context of the philanthropic context in the U.S, both in terms of religious as well as political and social contexts. The partnership between government agencies and faith-based institutions is an uneasy one, given the constant scrutiny that they come under, given the questions of separation of church and state (Bielefeld and Cleveland, 2013; p.469). As they point out, there are an estimated 47,000 to 58,000 independent Faith-Based Organizations (FBOs') in the U.S. giving figures from some scholars such as Stritt are pegged at an estimated $\$ 50$ billion annually (Stritt, 2008 ; p.730). Stritt has called for a closer examination of the potential contribution to social services that the faith-based NGOs make.

The economic recession took a toll on the religious giving sector as well, considering the findings of The 2013 Congregational Impact Survey ${ }^{\text {iii }}$, released by the Lilly School of Philanthropy in partnership with the Lake Institute on Faith and Giving. While the study was conducted with mostly Christian congregations (a total of 3,013 ) in the U.S, it is representative of the general trend in giving and this makes it significant.

One of the key findings of the survey is that congregational giving is improving financially.
"However, those with older attendees and those whose clergy are uninformed about congregational giving are experiencing the greatest challenges," the report points out (Congregational survey 6). As Giving USA 2011 data indicates, charitable contributions to religious organizations is estimated to be $\$ 95.99$ billion, two and half times as much as education, the next largest category. Overall, there has been a decline of $1.7 \%$ since 2010 due to decreased church attendance and lack of religious affiliation (Congregational Survey, 2013, p. 9).

\section{Methodology}

The data for this research came from the COPPS Dataset maintained at the Lilly School of Philanthropy as well as annual reports of three of the largest American Muslim NGOs. These NGOs were treated these as 'paradigmatic cases,' which tell us about the field of American Muslim NGOs (Yin, 2009).

To answer the research questions outlined, the following procedures were carried out (a) Analysis for Descriptive Statistics and (b) T-tests- to determine the sample means and compare them over the years.

None of these statistical procedures are generalizable to the population. While the objective is to investigate the patterns of giving, there is no claim to generalizability to the entire population as a whole, given the small population size. The paper aims at more 'analytical generalization,' across the category of NGOs and individuals under study. This, one can argue, can tell us a lot about the changing dynamics of the field.

\section{What the Data is telling us: Giving USA and COPPS Dataset}

Data from Giving USA and Center on Philanthropy Panel Study (COPPS) provides the most comprehensive pattern of giving across the country. As the chart below shows, total individual giving, as a percentage of Gross Domestic Product has stayed quite consistent, around 2\% from the 1970 s to 2012 (Fig. 1).

\section{Source: Giving USA}

Giving is also hypothesized to be correlated to the broader macro-economic trends. The chart below demonstrates this relationship and this again seems to be quite consistent through the decades (Fig. 2).

\section{Source: Giving USA}

As Dr. Patrick Rooney, Associate Dean for Academic Affairs and Research points out, roughly 9 out of 10 dollars in philanthropy come from individuals, if one were to include family foundations in the individuals category (Fig. 3). 
Individual giving as a percentage of disposable personal income, 1972-2012

(in current dollars)

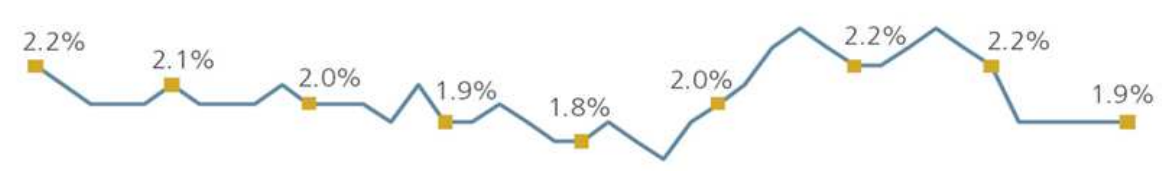

\begin{tabular}{lllllllll}
\hline 1972 & 1977 & 1982 & 1987 & 1992 & 1997 & 2002 & 2007 & 2012
\end{tabular}

Fig 1. Caption - Changes in individual giving, over a period of time

Total charitable giving graphed with the Standard \& Poor's 500 Index, 1972-2012 (in billions of inflation-adjusted dollars, $2012=\$ 100$ )

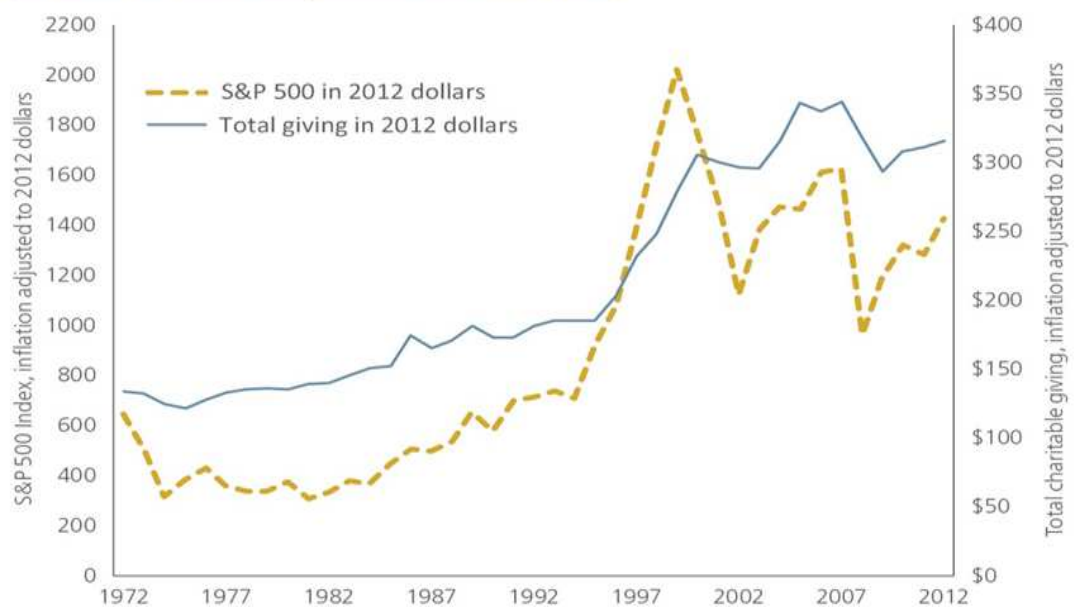

Fig 2. Charitable giving compared to inflation variation, over a period of time

Total giving in 2012 was estimated at \$ 316.23 billion, showing a slight increase over the previous year. As researchers at the Lilly School of Philanthropy pointed out: "The 3.5\% year-over-year growth rate $(1.5 \%$ adjusted for inflation) in gifts from American individuals (both households and bequests from their estates), corporations and foundations matches the same figurative portrait of 2012's economic indicators-some trends were positive, others were negative, but overall, there was growth. Federal tax policy shifts likely also played a role in giving decisions made last year." (Lilly School of Philanthropy Website).

Further, this observation is interesting to note: "As in the economy overall, some aspects of giving are growing more than others," said Gene Tempel, Ed.D., CFRE, founding dean of the Indiana University Lilly Family
School of Philanthropy. "For example, the 9.9\% inflation-adjusted growth in corporate giving was driven by strong gains in corporations' pre-tax profits, which marks a bright spot. In contrast, foundation giving grew by $2.3 \%$ after adjusting for inflation (Fig. 4)." (Lilly School of Philanthropy Website).

Some of the other key findings in Giving USA 2013 (Lilly School of Philanthropy Website) are as follows:

- Religion-Declined 2.2\% if one adjusts for inflation. Religious organizations receive about roughly one third of all donations in the U.S

- Education-Increased an estimated $4.9 \%$ in one year from 2011 to 2012

- Human Services-Witnessed a 3.8\% increase over the previous year, this included disaster relief efforts such as Sandy 


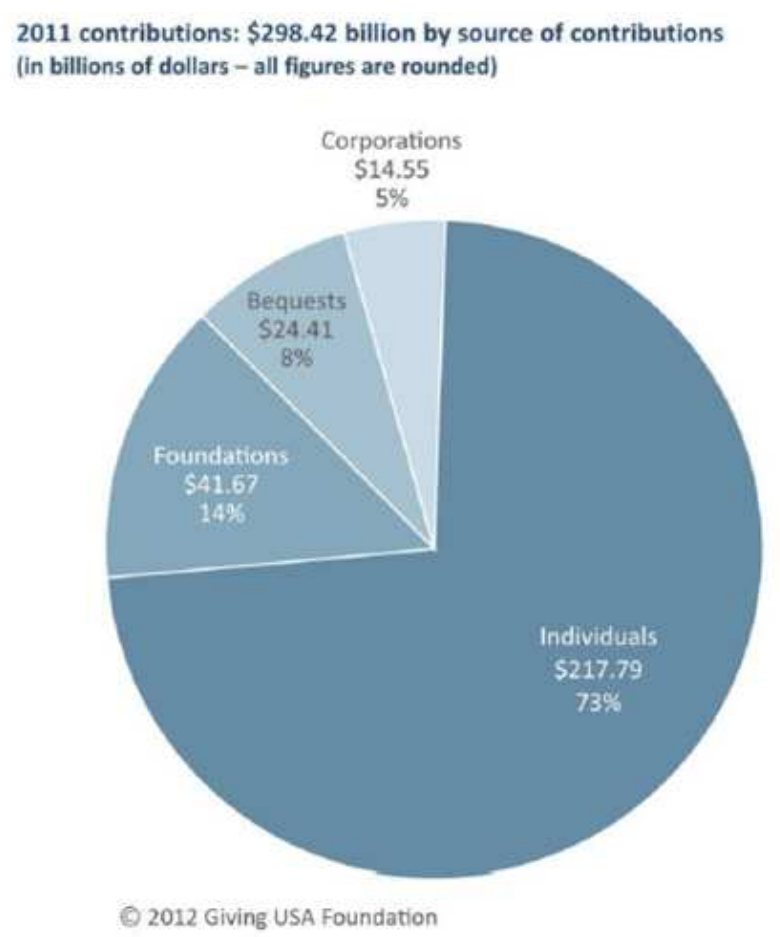

Fig. 3. Breakdown of total charitable giving in the U.S. by sources

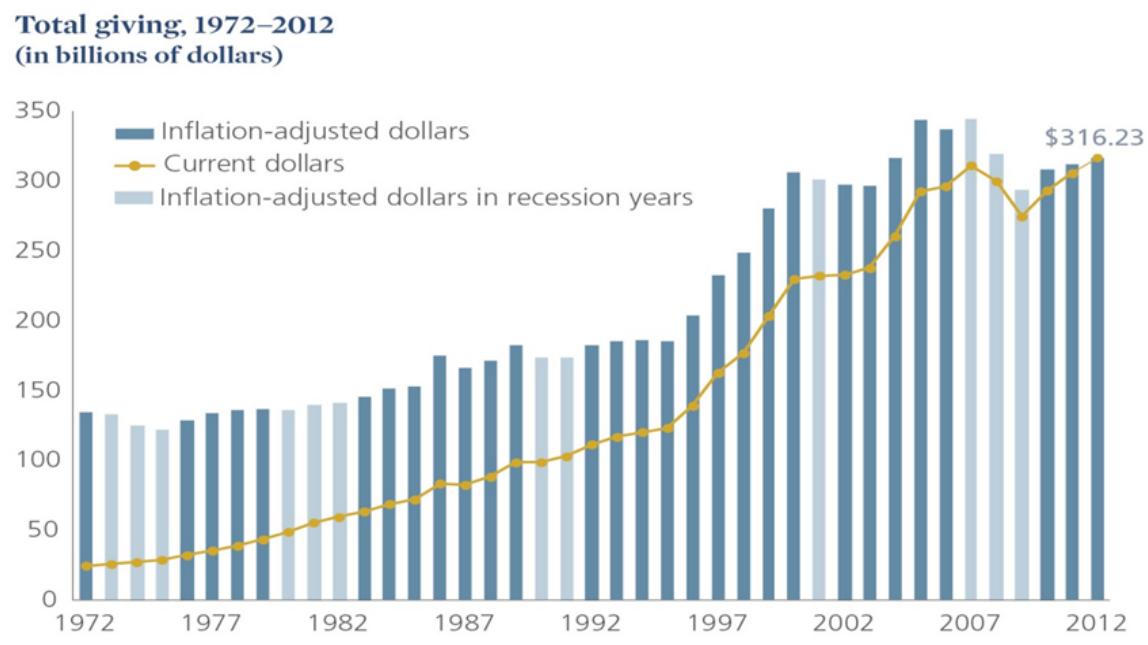

Fig. 4. Total giving, in terms of current dollar giving figures

Given this scenario across the country and an overall sentiment of recovery in the economy, how have the American Muslims fared, in the recent past? What has been the specific giving been in the last 10 years? We will turn to these questions now in the next section.

American Muslim Giving between 2002-12: Findings from COPPS data and Discussion

The dataset includes roughly 117 mainly Muslim families(though not all are Muslim), with data on
International giving, giving to local needs and a few other variables such as whether they gave to religious causes or secular causes. While the panel for the entire duration exists, I believe looking at cross-sectional data from two years i.e., 2001 and 2009 can offer us insights into the change in giving behavior (if any) in this period. The table below shows that the giving to religious causes declined among Muslims during this period, while the same occurred with secular causes. (See Appendix for descriptive statistics). 
Some other highlights from the dataset:

- Roughly $11 \%$ of Muslim families gave to Education, while $12.2 \%$ of the overall population gave to this category

- About $9 \%$ of Muslim families gave to International Causes, whereas it was $4.15 \%$ by the entire population, on average

- Amount given to social services (people in need) went up substantially between the ten years (see table above)

- Amount given to secular causes was $\$ 443$ by Muslims while it was $\$ 370$ by the entire population, on average

- Amount given to religious causes was $\$ 492$ by Muslims while it was $\$ 793$ by the entire population

While this gives us some insights into the giving behavior of American Muslim families, a look at the revenue figures of the three largest Muslim humanitarian NGOs' in the U.S gives us a perspective of how this sector is growing in the U.S. Taken together with the findings of this dataset, one can argue that this gives us an indication of the priorities of giving among American Muslims, though we need greater depth of data and a better survey to answer more pointed questions.

The amount of giving to secular causes seems to have increased and this can be seen as a reflection of some of the 'fear' of giving to 'Muslim,' causes around the world, that Zahra Jamal and others have talked about (Jamal, 2011). Post 9/11, there was much scrutiny of Muslim charities in the U.S. and around the world and in this climate, most American Muslims did not want additional attention drawn to their charitable activities. In this context, it is understandable that they would shift their philanthropy to causes which are considered less political and more 'neutral.' This is also the phase where the American Muslim 'identity' underwent a radial reexamination, as many scholars have pointed out (Siddiqui, 2014; Jamal, 2011).

The three NGOs' under study include Islamic Relief, Helping Hands and Mercy USA. Among all the three NGOs' there has been an overall increase in the revenues. These NGOs represent the largest ones of their kind in the U.S. and one can argue that these could be seen as 'paradigmatic,' in that sense (Yin, 2009). Given the adverse policy context in the U.S post 9/11, during which several Muslim NGOs' were shut down, there was a general fear complex and also slow-down in giving. There was also talk of a "chilling effect" on American Muslim giving (ACLU, introduction) which could impact the sector dramatically. But looking at the figures of these organization, one gets a sense that this has not occurred. Conversely, if this is taken together with the Giving USA data, the opposite may be true, that giving has not shifted substantially during the last ten years and has corresponded with more macro-economic changes, as Dr. Patrick Rooney and others have pointed out.

There are a few possible explanations for this:

There was a greater need for community solidarity, post September 11, 2001, since the American Muslim community felt under attack, as there were very high negative sentiments about Islam and Muslims, around the world (Haddad and Harb, 2014). The greater focus on their religious identity made many American Muslims focus on contributing to outside of the community, to build the perception of being more 'mainstream,' and more 'American.'

There was no perceptible impact on giving as the 'needs' and 'awareness' about philanthropy remained unchanged. These are among the eight factors that motivate giving, according to Bekkers and Weipking (2007). Given that the donors were aware of the need of charity for the causes they believed in, their philanthropic behavior remained unchanged.

The income of the NGOs can be taken as a proxy for a (part) of the philanthropic activities of American Muslims, as they are the most visible component of philanthropy. In data based on interviews, many leaders of NGOs pointed out that much of the income of NGOs comes from online donations (Khan, 2015). This is particularly true of large NGOs such as Islamic Relief, Helping hands etc. On the other hand, there is also the mosque level collection of funds. Islamic Relief claims to receive over $40 \%$ of its donations from online sources and this includes both Muslim and non-Muslim donors (Interview with Anwar Khan, CEO of Islamic Relief USA, October 2014).

This is most pronounced during the month of Ramadhan and occasionally, on Fridays as well. Finally, there are the government grants. Surprisingly, none of the NGOs mentioned here receive any government grants directly.

The giving to international causes is higher among American Muslims, as they are still predominantly an 'immigrant' community, where over $2 / 3$ are of immigrant origin, having immediate ancestry from outside of the U.S. according to a recent Pew Research.

\section{Emerging Trends in American Muslim Philanthropy}

While this section deals with some of the latest trends, this is just the beginning of a longer research project. In observing and interacting with several American Muslim and Arab American NGOs', I believe the following trends are noticeable:

- Institution building in the U.S

- Youth philanthropy

- Women's philanthropy

- Ethnic giving on the rise 


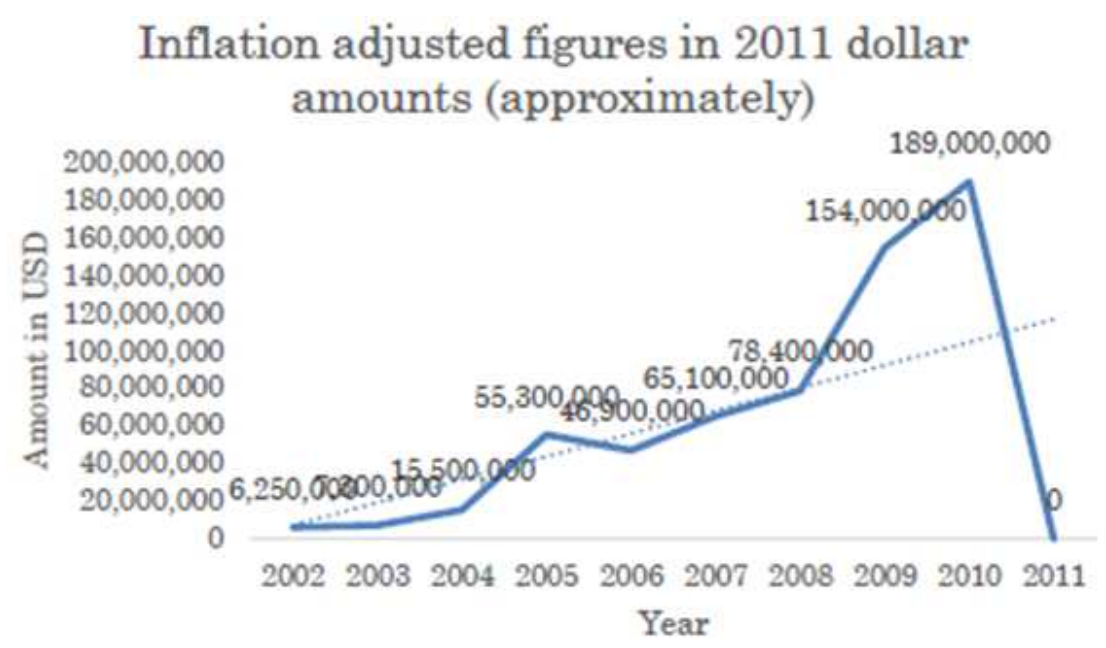

Fig. 5. Revenue figures for Islamic Relief between 2002-12. Source: Foundation Center website

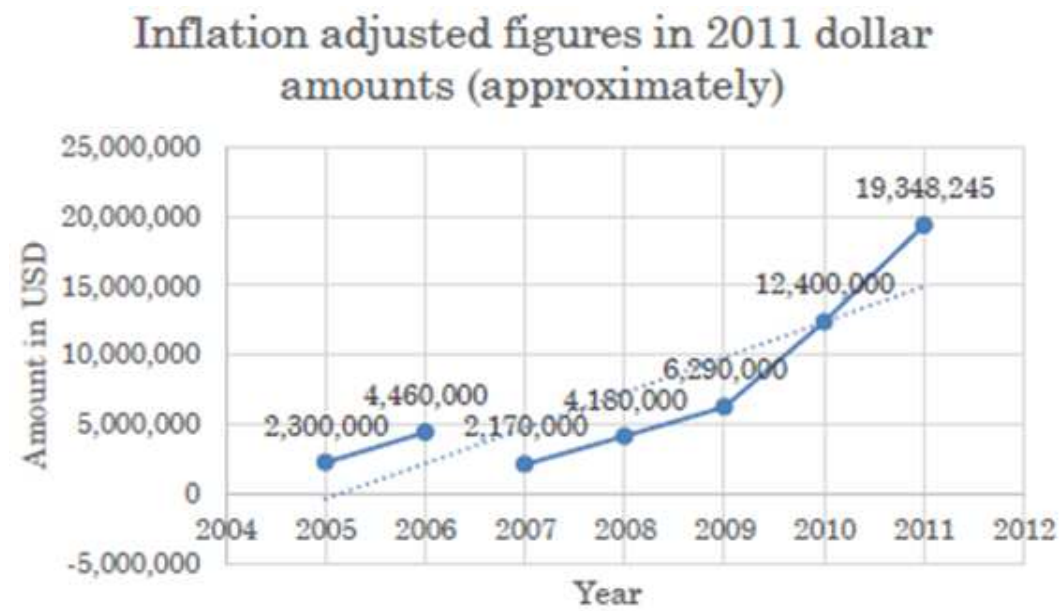

Fig. 6. Revenue figures for Helping Hands for Relief and Development between 2002-12. Source: Foundation Center website

\section{Inflation adjusted figures in 2011 dollar amounts (approximately)}

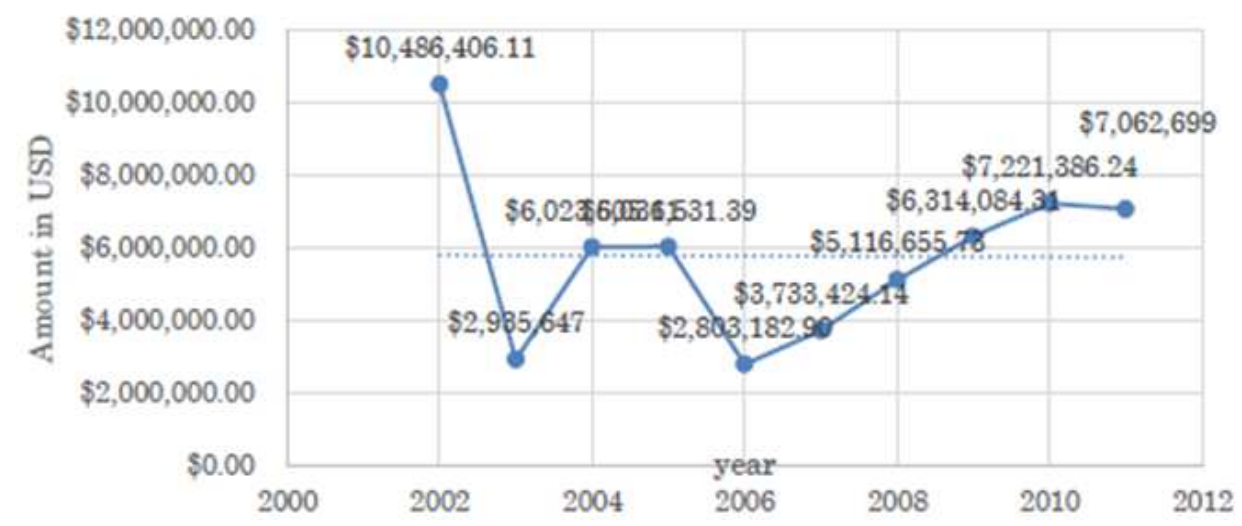

Fig. 7. Revenue figures for Mercy Relief International, USA between 2002-12. Source: Foundation Center website 
Let us look at each of the segments:

\section{Institution Building in the U.S}

Both at the local and national level. The Mosque Survey 2011 is just an indication of the level of activity in the American Muslim community. Muslim donors value trust in an organization as a key determinant in giving. The level of trust and giving seem to be directly correlated (Najam, 2006, p. 143), as in the case of the Pakistani American community, that Najam has studied extensively. Even though there is a general preference to give to individuals, the fact that the number of institutions is growing is reason to believe that there will be an increased demand for funding institutions and more formalized mechanisms of philanthropy. This institution building has included not only Islamic centers, mosques but also cultural centres, social service organizations across the country such as Dearborn based ACCESS, the largest Arab-American NGO in the U.S. and dozens of language and culture institutes catering to a wide array of communities that comprise the American Muslim communities. Ihsan Bagby's study has captured the growth of American Mosques in the last twenty years (Bagby, 2011). There has also been a growth in the phenomenon of humanitarian aid NGOs, that emerged post Gulf War II and have ever since continued to provide aid for people afflicted by conflicts, around the world. The likes of Islamic Relief, Helping hands are just examples of such NGOs and there are dozens of smaller ones that are carrying out similar work, around the U.S.

\section{Youth Philanthropy}

This is also an emerging trend in the American Muslim and Arab American community. With programs such as Teen Grant Making initiative, founded and managed by ACCESS and similar programs by Islamic Relief to encourage and teach youth in philanthropy, the segment seems all set to grow.

\section{Women and Philanthropy}

There is a growing recognition of the role of women in philanthropy, given the various discourses in the field- coming from feminist traditions, studies in state power structures as well as nonprofit management (McCarthy, 1996; 334). As she points out, several theoretical models have been used to understand and explicate the field including "weak state/strong state paradigms, questions concerning the universality of 'materialist agendas' for mothers and children; the import of differing philanthropic strategies, 'parallel power structures' and public/private partnerships; and the relative importance of religion, government, demographics and economic trends in shaping women's roles"
(McCarthy, 1996, p.333). Organizations such as ASMA society, Global Partnership for Women and Girls, Iranian American Women's Foundation are not only contributing to the efforts in this space, but also shaping discourses surrounding women's philanthropy.

\section{Ethnic Giving on the Rise}

There is also an increased focus on ethnic giving, as the number of wealthy individuals among minorities is rising. As Dr. Una Osili, Director of Research, Lilly school of Philanthropy points out, in the introduction to an essay by Lilya Wagner: "There is a need to adapt strategies and tactics in order to honor and appeal to the increasingly multi-cultural backgrounds, traditions and motivations of donors to charitable causes" (Seiler et al., 2010, p. 183). As she further adds that increased diversity can have a negative effect for philanthropy towards collective causes, ethnic diversity can increase the probability of contributions and total amount contributed as more diverse groups form their own organizations.

Lilya Wagner points out in her chapter Ethnicity and Giving that ethnicity and diversity forces us to re-think and examine issues, going beyond a "one size fits all" approach (Tempel et al., 2011, p.185). As ethnic minority groups grow in influence and wealth, their philanthropic activities are rising too. In the case of American Muslim community, one is already seeing the proliferation of ethnic organizations such as Association of Pakistani Physicians (APNA), considered one of the most influential ethnic groups in the country. Anft quotes federal income tax data to point out that Hispanics and Blacks give more of their proportion of wealth, as compared to the general population (qtd. In Tempel et al., 2011, p. 185).

Figure 5-7 as the figures show, each of these NGOs have had an increase in donations over a period of time since 2001. This contradicts some of the claims made by activists that there has been a devastating impact of legislation on Muslim charity. While it is true that there was (and still is) to some extent, a fear complex among Muslim American communities, this fear has not resulted in a drastic reduction in giving towards Muslim American causes/organizations.

\section{Conclusion}

I have argued in this study that American Muslims are engaging in philanthropy as a means of creating linkages within the community, as well as in terms of forming an 'American identity'. As Shariq Siddiqui has argued in his dissertation Navigating Identity through Philanthropy (2014), philanthropy has been a means for American means to express their identity. This has taken the form of building institutions, community centers as 
well as supporting projects- in the realm of culture production, education, research etc. that support the long-term vision of establishing Islam firmly in the U.S., as an 'American religion'. While constitutionally, this has been guaranteed and there are no substantial threats to the American Muslim community, of late, there has been a climate of fear and suspicion towards the community, as evidenced by the reports of New York Police Department Surveillance and related measures taken post 9/11, as part of the Global War on Terror (Haddad and Harb, 2014).

There are a few challenges to effective American Muslim philanthropy and one of them is the way in "conforming their circumstances to the realities of their day-to-day lives," as Ghaneabassiri points out (GhaneaBassiri, 2011, p.75). He further argues that academically, there needs to be new analytical categories and a vocabulary that allows for a representation of the historical realities of Islam in America. This is corroborated by the findings of Robert Wuthnow, who has pointed out that the increased diversity in the U.S can be an opportunity only when people make the effort to reach out and work with each other.

In the realm of faith-based giving, there are also a few challenges to the Muslim congregations, which are quite similar to the mainstream American Christian congregations. As the 2013 Congregational Survey (Congregational Survey 2013, p.13) points out, some of the findings that are key to fundraising in a faith-based institution are also relevant to the Muslim faith-based sector as well. Key among them are:

- Relationship Management: Maintaining personal relationships with donors and learning of their passions, desires and motivations to give

- Vision: Articulating a clear vision

- Trust: Maintaining transparency about how money is received and spent

- Faith formation: Giving is a reflection of the donor's religious values and beliefs

\section{Notes}

${ }^{\mathrm{i}}$ For a paper based entirely on Literature review of the field, pls see my paper titled Researching American Muslim giving-Challenges and Opportunities. Working paper series. Lilly School of Philanthropy (np).

${ }^{\mathrm{ii}}$ This section is borrowed from my paper on lit. review of American Muslim giving titled Researching American Muslim giving-Challenges and Opportunities. Working paper series. Lilly School of Philanthropy (np).

iii The 2013 Congregational economic Impact Survey. Lilly School of Philanthropy. Indiana University Press. 2013. Print.

\section{Acknowledgment}

I would like to thank Dr. Una Osili, Professor of Economics and Director of Research, The Lilly Family School of Philanthropy, Dr. Amy Thayer, former Associate Director of Research, Lilly School of Philanthropy and Amir Hayat, Statistician - for their invaluable help in analyzing the data and framing the research questions for this article.

\section{Ethics}

There was no conflict of interest in writing this article. I am grateful to the insights from Dr. Shariq Siddiqui and others, cited in this paper, for their insights and advise.

\section{References}

Tempel, E.R., T. Seiler and E.E. Aldrich, 2011. Achieving Excellence in Fundraising. Jossey Bass press, SF, CA.

Bagby, I., 2011. The American mosque. CAIR, Washington D.C.

Bielefeld, W. and W. Cleveland, 2013. Faith-based organizations as service providers and their relationship to government. Nonprofit Voluntary Sector Q., 42: 459-472. DOI: $10.1177 / 0899764013485160$

Bekkers, R. and P. Wiepking, 2007. Generosity and philanthropy: A literature review. SSRN. Online.

CAIR, 2011. The American Mosque: Basic characteristics. Washington D.C.

Congregational Survey, 2013. Lilly School of Philanthropy. Indianapolis.

GhaneaBassiri, K., 2011. A History of Islam in America: From the New World to the New World Order. 1st Edn., Cambridge University Press, New York, ISBN-10: 0521849640, pp: 446.

Haddad, Y. and N. Harb, 2014. Making Islam an American Religion. Religions. MDPI Press.

Jackson, J.W., 2008. The wisdom of generosity - A reader in American Philanthropy. Baylor University Press.

Jamal, Z., 2011. Charitable Giving among American Muslims: Ten years after 9.11. Institute For Social Policy and Understanding (ISPU), Washington D.C.

Khan, S., 2015. American Muslim philanthropy in flux: Effects on community building and identity formation. Diss. Virginia Tech.

McCarthy, K., 1996. Women and philanthropy. Voluntas, 7: 331-335. DOI: 10.1007/BF02354156

Najam, A., 2006. Portrait of a Giving Community: Philanthropy by the Pakistani-American Diaspora. 1st Edn., Harvard University Press, Cambridge, ISBN-10: 0674023668, pp: 231. 
Seiler, T.L., E.E. Aldrich and E.R. Tempel, 2010. Achieving Excellence in Fundraising. 1st Edn., John Wiley and Sons, San Francisco, ISBN-10: 0470551739, pp: 592.

Siddiqui, S., 2014. Navigating identity through philanthropy: A history of Islamic society of North America (1979-2008). PhD Thesis, Indiana University.
Stritt, S.B., 2008. Estimating the value of the social services provided by faith-based organizations in the United States. Nonprofit Voluntary Sector Q., 37: 730-742. DOI: 10.1177/0899764008321802

Yin, R.K., 2009. Case Study Research: Design and Methods. 3rd Edn., Sage Publications, Los Angeles, ISBN-10: 1412960991, pp: 219.

\section{Appendix: Descriptive Statistics from COPPS data on American Muslim Giving}

tabulate Muslim
\begin{tabular}{r|rrr} 
Muslim & Freq. & Percent & Cum. \\
\hline 0 & 8,080 & 98.57 & 98.57 \\
1 & 117 & 1.43 & 100.00 \\
\hline Total & 8,197 & 100.00 &
\end{tabular}

Amount given to international causes of Muslim

\begin{tabular}{l|rrrrr}
. sum Aint 1 if Muslim==1 & & & \\
Variable & obs & Mean & Std. Dev. & Min & Max \\
\hline Aint1 & 117 & 18.46154 & 117.4798 & 0 & 1200
\end{tabular}

Percentage who gave to Intl. Causes:

\begin{tabular}{|c|c|c|c|}
\hline $\begin{array}{r}\text { Internaltio } \\
\text { na } 1 \\
\text { aid/peace } \\
\text { giving } \\
\text { indicator }\end{array}$ & Freq. & Percent & Cum. \\
\hline $\begin{array}{l}0 \\
1\end{array}$ & $\begin{array}{r}106 \\
11\end{array}$ & $\begin{array}{r}90.60 \\
9.40\end{array}$ & $\begin{array}{r}90.60 \\
100.00\end{array}$ \\
\hline Tota 1 & 117 & 100.00 & \\
\hline
\end{tabular}

\begin{tabular}{|c|c|c|c|}
\hline $\begin{array}{r}\text { Interna } 7 \text { tio } \\
\text { na } 1 \\
\text { aid/peace } \\
\text { giving } \\
\text { indicator }\end{array}$ & Freq. & Percent & Cum. \\
\hline $\begin{array}{l}0 \\
1\end{array}$ & $\begin{array}{r}8,123 \\
352\end{array}$ & $\begin{array}{r}95.85 \\
4.15\end{array}$ & $\begin{array}{r}95.85 \\
100.00\end{array}$ \\
\hline Tota 1 & 8,475 & 100.00 & \\
\hline
\end{tabular}

Sum spent on Education

\begin{tabular}{|c|c|c|c|c|c|}
\hline variable & obs & Mean & std. Dev. & Min & $\max$ \\
\hline Aeduc & 8475 & 57.97617 & 728.1233 & 0 & 50000 \\
\hline Variable & obs & Mean & std. Dev. & Min & $\max$ \\
\hline Aeduc & 117 & 48.33333 & 249.4727 & 0 & 2000 \\
\hline
\end{tabular}

Number of people who gave to Education 


\begin{tabular}{r|rrr}
$\begin{array}{c}\text { Education } \\
\text { giving } \\
\text { indicator }\end{array}$ & Freq. & Percent & Cum. \\
\hline 0 & 7,437 & 87.75 & 87.75 \\
1 & 1,038 & 12.25 & 100.00 \\
\hline Tota1 & 8,475 & 100.00 &
\end{tabular}

Number of Muslim families that gave to Education

\begin{tabular}{r|rrr}
$\begin{array}{c}\text { Education } \\
\text { giving } \\
\text { indicator }\end{array}$ & Freq. & Percent & Cum. \\
\hline 0 & 103 & 88.03 & 88.03 \\
1 & 14 & 11.97 & 100.00 \\
\hline Tota1 & 117 & 100.00 &
\end{tabular}

Secular giving Muslim and entire population

- sum Asecu1ar04

\begin{tabular}{r|rrrrr} 
Variable & obs & Mean & Std. Dev. & Min & Max \\
\hline Asecular04 & 8475 & 370.5929 & 1484.758 & 0 & 55000
\end{tabular}

. sum Asecular04 if Mus lim==1

\begin{tabular}{r|rrrrr} 
Variable & obs & Mean & Std. Dev. & Min & Max \\
\hline Asecular04 & 117 & 443.8974 & 1265.893 & 0 & 10000
\end{tabular}

Religious giving by Muslim and the entire population

- sum Arelig

\begin{tabular}{r|rrrrr} 
Variable & obs & Mean & Std. Dev. & Min & Max \\
\hline Arelig & 8475 & 793.5415 & 2459.587 & 0 & 85000
\end{tabular}

. sum Arelig if Muslim==1

\begin{tabular}{r|rrrrr} 
Variable & obs & Mean & Std. Dev. & Min & Max \\
\hline Arelig & 117 & 412.3162 & 1243.768 & 0 & 10725
\end{tabular}

